\title{
Elaboration of Balance-Optimization in Economic and Mathematical Model of Development of a Large Municipal Unit: Real Experience
}

\author{
Alexander S. Novoselov*, Alexey E. Kovalev, \\ Egor A. Gaiduk and Gagik M. Mkrtchyan \\ Institute of Economics and Industrial Engineering of SB RAS \\ 17 Akademika Lavrent'eva, Novosibirsk, 630090, Russia
}

Received 21.06.2019, received in revised form 02.12.2019, accepted 09.12.2019

The objective of the study is to develop a balance-optimizing economic and mathematical model which enables predicting steady and sustainable development of a large municipal unit. Using the method of dynamic programming introduced by Richard Bellman, the authors worked out the economic and mathematical model for optimizing the key indicators of social and economic development of a municipal unit. The model used and predicted indicators included in the list of the key performance indicators of municipal unit authorities. There is an analysis of the results of applying the model for a large municipal unit - Novosibirsk. The calculations made by the authors indicate that the model may work with actual economic information and may be used for predicting and making managerial decisions at a municipal level.

Keywords: modelling, forecasting, strategic planning, management, municipal unit.

The research was done with the plan of research work of IEIE SB RAS for the project XI.173.1.2 "Strategic management of regional and municipal development: concept and principles of implementation” No. AAAA-A17-117022250118-6.

Research area: economics.

Citation: Novoselov, A.S., Kovalev, A.E., Gaiduk, E.A., Mkrtchyan, G.M. (2019). Elaboration of balance-optimization in economic and mathematical model of development of a large municipal unit: real experience. J. Sib. Fed. Univ. Humanit. Soc. Sci., 12(12), 2258-2276. DOI: $10.17516 / 1997-1370-0521$. 


\section{Introduction}

Applying a systematic approach to management in order to improve the efficiency of management decisions involves adapting multifunctional economic and mathematical tools for the decisions at the regional and municipal levels. Determining the directions, factors and conditions of sustainable social and economic development of a region or municipal unit in cooperation with other municipal, regional and federal governments requires the use of analytical tools to ensure systematic representation of the interconnections and processes of functioning of all parts of the regional and municipal economy. This analytics should balance the needs of economic actors (municipal units) and opportunities to meet them, the possibility of predicting the trajectories of economic and social development for various scenarios, including those concerning different levels of government with different planning horizons.

At present, the efficiency of social and economic development of municipal units is assessed in many ways, with the constantly developing system of indicators characterizing the achievements in these areas (Leksin, 2012). In particular, there were approved indicators for assessing the efficiency of the local self-government bodies in urban and municipal districts in accordance with Resolution of the Government of the Russian Federation No. 1317 " On Measures to Implement Decree of the President of the Russian Federation No. 607 dated April 28, 2012, On Assessment of the Performance of Local Self-Government Bodies in Urban and Municipal Districts" dated December 17, 2012 ${ }^{1}$, and Paragraph 2 of the Decree of the President of the Russian Federation No. 601 "On the Main Directions of Improvement of the Public Administration System" dated May 7, 2012 ${ }^{3}$. In addition, the list of indicators for assessing the efficiency of local government includes natural indicators, such as the number of municipal institutions of general education, health facilities, and relative indicators, which are given per capita or as a percentage of the established standards.

In the process of practical activities, the administration of a municipality (municipal unit) has the authority to influence the economy through the implementation of various projects, financing, subsidies and administrative, legislative support of a particular direction of its development. All these impacts are usually called controlling actions.

Decree of the President of the Russian Federation No. 607 "On Assessment of the Performance of Local SelfGovernment Bodies in Urban and Municipal Districts" dated April 28, 2008.

2 Resolution of the Government of the Russian Federation No. 1317 "On Measures to Implement Decree of the President of the Russian Federation No. 607 dated April 28, 2012, On Assessment of the Performance of Local Self-Government Bodies in Urban and Municipal Districts" dated December 17, 2012.

3 Decree of the President of the Russian Federation No. 601 "On the Main Directions of Improvement of the Public Administration System" dated May 7, 2012. 
Decisions taken by municipal government are realised in changes in the revenue and (or) expenditure part of the municipal budget and (or) change in the qualitative indicators describing meeting the needs of the population in each financial cycle. Such decisions, as a rule, have long-term consequences, which exert a significant impact on the indicators of municipal development for several years. At the same time, the most important component of municipal governance is the budget process, and budgetary replenishment becomes one of the main criteria for evaluating the efficiency of the work of government bodies. Various forms of budget items should contribute to growth and equalization of spatial economic development indicators. Budgetary replenishment and use of budgetary funds of the municipality is conditioned by the properties of the financial and budgetary system, in which the change of some factors affects the other in a certain perspective. In light of this, adding funds to the budget depends not only on management decisions taken in previous periods, but rather it is the result of a whole set of factors, many of which can and should be governed by the authorities (Marshalova and Novoselov, 2011).

The development of municipal units in the Russian Federation stands upon the decisions implemented by regional authorities to a great extent. Municipalities act as the backbone for the implementation of regional development programmes (Seliverstov, 2016). In order to improve the balance of decision-making in municipal management, taking into account long-term goals, it is necessary to improve the economic and mathematical tools at the regional and municipal levels.

\section{Methodology}

Measuring and predicting the complex of factors involved in municipal development is quite a complicated task. In these conditions, the research in the field of modelling the social and economic development of the municipal units becomes especially relevant, as this modelling fosters building a plan-forecast in the long run, which would embrace interdependence of key indicators, based on the concept of a municipal unit as an integral balanced system. The models to be created should facilitate this task and provide guidelines for effective municipal management. Meanwhile, the creation of a system of planning and forecasting documents is a necessary condition for the formation of an effective management system (Novoselov, Marshalova, Burmatova, 2018).

The aim of the present study is to build a balance-optimizing dynamic model, which allows for the forecasting of sustainable progressive development of a large municipality. 
The research methodology is contingent on the balance-optimizing model of the municipality offered by the Institute of Economics and Industrial Engineering SB RAS. The novelty of the authors' original methodological approach consists in the development of a management model that 1) sets out conditions for real economic independence and increased engagement of municipalities as regards the implementation of economic development strategies, and 2) suggests the use of dynamic modelling techniques. The originality of the approach lies in the fact that during the development of the model the municipal economic system was considered as a part of the modern management system, which implies its openness. At the same time, the economy of the municipality is presented as a set of interrelated subsystems, which due to the intricate balance and optimization modelling and forecasting of the dynamics of social and economic development, is accompanied with plans to achieve joint and private target indicators. Above and beyond, the achievement of target values of social and economic development indicators is ensured under the conditions of meeting balance ratios and resource constraints.

\section{Modelling as an element of the management system in a municipal unit}

Development of models of multipart economic systems has a long tradition maintained both in Russia and abroad (Granberg, 1985). The problems of modelling various aspects of municipal governance have been studied by many specialists; over the past twenty years, the following Russian and foreign scientists have made a significant contribution to these studies. These prominent figures include A.R. Bakhtizin,
A.N. Biriukov,
O.I. Glushchenko,
V.N. Leksin,
A.A. Mitsel',
S.A. Suspitsyn,

T. Iu. Chernysheva, P. Bayer, V. Henderson, N. Wang, etc.

Foreign experience in the field of modelling the development of municipal units is concentrated mainly in the field of application of general equilibrium models. These works are connected primarily with the choice of optimal functional forms for the description of markets and economic subjects, setting various a priori assumptions, extended explanations of external conditions, the transition from exogenous to endogenous definition of model parameters, etc. Herewith, the choice of functional forms and other parameters of modelling is made within the framework of solving a separate specialized task or given problems, for example, such as the housing market at the municipal level (Bayer, McMillan, Rueben, 2004; Tscharaktschiew and Hirte, 2009), demography of a certain city (Kingsland, 1995), the impact of migration on the 
economic growth of the municipal unit (Feler and Henderson, 2008), externalities in the urban economy (Verhoef and Nijkamp, 2003), and other problems of municipal development (Bergman and Jorgenson and Zalai, 1990; Devarajan and Robinson, 1990; Henderson and Wang, 2005; Lofgren and Harris, Robinson, 2002; Lucas, 1988).

A striking example of a systematic approach to urban development modelling is the work by D. Black, V. Henderson Urban Growth (Black and Henderson, 1997). In this work, they modelled the development of cities, each of which specializes either in the production of type A (means of production) or type B (means of consumption). The growth, development and interrelation of these cities is viewed from the standpoint of several parameters, including migration, household income, employment, and consumption.

This direction of research was continued and expanded by E. Rossi-Hansberg and M. Wright in the work Urban Structure and Growth (Rossi-Hansberg and Wright, 2006). In this work, the authors develop the previously proposed theory based on the rejection of the division of cities into two types. It is taken for granted that cities contain both types of production concentrated at an exogenously defined point. We inspected variants of migration of the population striving to maximize their income and minimize their costs (renting, housing, commuting to the place of work) or to increase their level of education. Cobb-Douglas production function is used to describe employer firms, which incorporates human capital with the number of workers. Ultimately, the model demonstrates the relationship between the efficiency of the spatial organization of the city and the level of economic return on the factors of production that it possesses (in particular, land and human capital). Nevertheless, the model does not include municipal authorities as active agents influencing the development of the urban economy and management.

Thus, these models are for the most part of a theoretical nature and, consequently, are more appropriate for identifying individual patterns and testing the hypotheses put forward by researchers than for practical application. The result of the assessment whether a particular economic policy based on models of this type and conducted by local administrations turns out to be effective will depend to a large extent on the specification of functional forms in the description of economic agents.

The approaches outlined in the works of Russian authors differ both in the set of modelling and analysis tools and in the choice of the research object. As well as their foreign colleagues, Russian scientists do not scrutinize the municipal unit as a whole, but some of its functions or processes only. As a rule, they dwell on the distribution of 
financial means, other limited resources or tax burden. The works of Russian specialists can be conditionally divided into two main groups: qualitative and quantitative ones. These approaches are not mutually exclusive and, in fact, they complement each other. Concurrently, their joint application makes it possible to use the available information to the best and, as a consequence, to obtain more coherent models in terms of their compliance with the conditions observed in the object's life and their applicability in management practice.

An example of the use of qualitative analysis is presented in the article by A.A. Mitsel' and A.A. Zakharova "Application of Non Distinctive Linguistic Models during Elaboration of the Strategies for Municipal Unit Development" (Mitsel', Zakharova, 2005). The authors use the SWOT analysis method to study the internal and external environment of the municipal unit. The application of this method is premised on that in management (viz. strategic or current management) decisions are often made on the basis of expert assessments, which, as a rule, have qualitative rather than quantitative values.

In the article "Hierarchical Evaluation Model of Social and Economic Development of Municipal Unit" (Chernysheva, Zakharova, Mitsel', 2008) the aforementioned authors together with T. Yu. Chernysheva supplemented their research with quantitative analysis methods to solve the problem of assessing the impact of various actors on the expected final result of the coordinated programme for city development. From our point of view, a serious drawback of the described model is its inapplicability for solving the problem of limited resources distribution, which is very relevant for any business entity and municipal unit. Moreover, the given interpretation of the model is created taking into account a number of simplifying assumptions, which significantly reduces the efficiency of its application.

The article by A.N. Biriukov and O.I. Glushchenko "Methodology of Two-Level Distribution of the Municipal Budget on the Basis of the Neuronet Model" (Biriukov and Glushchenko, 2006) describes the experience of using quantitative analysis for calculating the distribution of municipal financial resources selected as the main object of the present research. The described methodology covers a wider range of indicators and is much closer to solving real problems of municipal finance than the previous approach. What is more, the model touches upon the spatial aspect by considering not the only one, but all municipality units within the territory of a given region. The authors examine the research object in the light of two levels of budgetary relations: municipal units and municipal institutions within the municipal unit. In order to assess 
the performance of institutions in the reporting period, we shall build a neural network model, which is unique in terms of training methods. This work represents a separate branch of research on the basis of neural network models, but its applicability for the development of plans for social and economic development of the municipal units at the moment, in our opinion, is very limited.

The next proposed model solves a narrowly specialized problem of municipality management. O.A. Krakashova in her work "Economic-Mathematical Model of Financing Communal Infrastructure of Municipal Unit" (Krakashova, 2008) used Bellman's Principle of Optimality to solve the optimization problem of distributing investment resources among the finite number of projects aimed at restoring the engineering networks of the municipal unit. This research is an example of the use of dynamic programming methods to find the optimal distribution of financial resources in the municipality. The optimization problem of dynamic programming with maximization of the total economic effect from the implementation of all these projects for the municipality is to be solved with a plan of distribution of financial resources among these projects. The author proposes to use the integral indicator as a measure of economic effect, as it takes into account a number of utility criteria of specific projects introduced by the author. However, neither the integral indicator itself, nor approaches to its development have been suggested.

This is the ongoing process of development of management tools in the form of economic and mathematical models for the municipal unit, as well as of their internal and external changing in Russia at the moment. More and more often the authors resort to multistage analysis, at the same time they use various approaches aimed at improving the quality of the final results of the research.

There are not enough researches in the economic literature that consider municipality as a whole, as a system. The authors of the researches frequently choose separate directions of activity for their analysis, which can be explained, among other reasons, by insufficient development of computer products, which are not able to take into account all the necessary data, limitations and interrelationships for obtaining high quality results so far.

\section{The dynamic model of municipality's development}

During the research the authors used their own economic and mathematical model which reflects the changes occurring in the modelled municipality. The model was based on the assumption that the development of a municipality is subject to a cyclical 
process in which the fiscal-budgetary cycle is equal to one year in duration. There are important managerial decisions to take at each step, which would influence the budget replenishment and the use of the money not only in the current year but also in the next years (to a lesser extent). Such decisions affect the qualitative non-financial indicators of the city development. Description of this process corresponds to the problem of dynamic programming. Bellman equation was used to create a model of dynamic programming in relation to the municipal unit.

Bellman equation allows us to find an optimal solution for a multidimensional problem by decomposing it into stages, each of which represents a subtask relative to one variable. The advantage of such an approach is that instead of a multidimensional problem one-dimensional optimization problems are solved at each stage. This generally corresponds to the characteristics of the budget process and annual planning in a municipal unit. In particular, long-term planning of municipal development allows for interpretation as a multistep decision-making process. The degree of solving the problems faced by a municipality is measured in the form of key indicators but it does not have a maximum limit in the long run, while retaining its structure as a whole. Achieving these objectives is described via the application of multiple parameters. The choice of (managerial) solution at each step does not affect the previous decisions (Novoselov, Gaiduk, Kovalev, 2016).

The developed model covers various indicators characterizing the development of a municipal unit. In the research there is a large amount of calculations carried out with the help of this model in such a way that modern computers can promptly perform all the necessary calculations with minimal human involvement.

The model has the following features:

- use of R. Bellman's method;

- calculation of the integral indicator which characterizes the development of the municipal unit completely;

- calculation of indicators of "perturbation" which characterize the expected attitude of the population to the solution of a certain list of tasks faced by municipal management.

The values of variables in the dynamic programming model are determined year after year. The result of calculations for one year is entered into the equation for the next year. In this case it is possible to obtain the results of solving the problem for any point with timely performing sequential calculations. The model is a system of interrelated units reflecting different aspects of the municipality's activities: 
- demographic block;

- economic block;

- block of housing and communal services;

- education block;

- healthcare and municipal property block;

- consumption block.

The model uses an integral optimality criterion that sums up the criteria of the optimality of each stage. The described process of finding the optimal solution at each stage is presented in Fig. 1 (Gaiduk, Kovaleva, 2013).

Municipal unit is represented by the dynamic system $X$ in order to use the concept of Bellman. The condition of the system at the moment $t$ is described by the vector demonstrating social-economic growth $x_{t} \in R^{n}$ (the coordinates correspond to the indicators of growth), where $x^{0}$ is the current condition of the system and $x_{N}$ is the target condition of the system, which is to be reached at the end of software period $t=N$.

The changing condition of the system from $x_{t}$ to $x_{t+1}$ is carried out under the effect $u_{t} \in R^{m}$ (controlling action in the year $t$ according to functional dependence $x_{t+1}=Q\left(x_{t}, u_{t}\right)$ ). As the difficulty of the system concerning municipal unit presupposes the effect from each $u_{t}$ (for instance, investment project) on some growth indicators in different spheres of municipal unit simultaneously, the vector of controlling actions should be displayed as the matrix vector with dimension $(2 \times l)$ (Fig. 2).

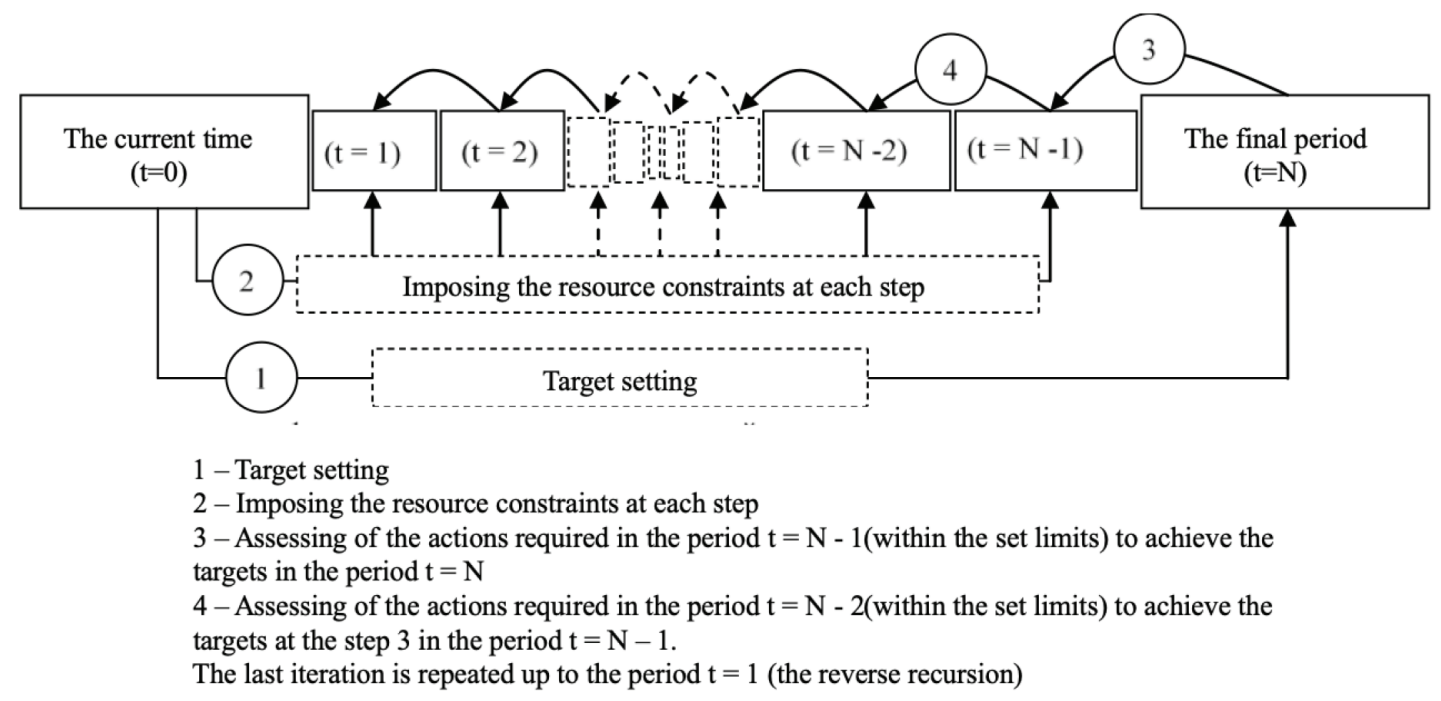

Fig. 1. Circuit diagram of iterative optimization of key indicators under the scarcity of resources 


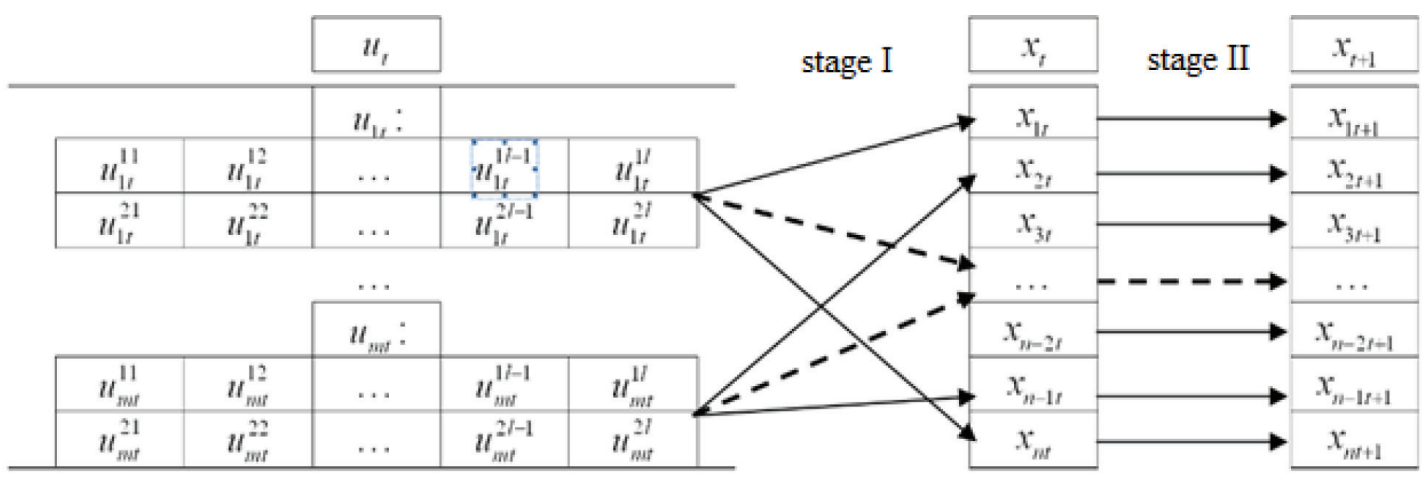

Fig. 2. The vector of controlling actions matrix $u_{x}$ effect on system $X$

The first row of each controlling action in the matrix includes the elements $u_{i t}^{1 j}$ expenditures on its realization (where $m$ is the number of controlling actions in the year $t, l$ is the expenditure influencing realization of controlling actions, $i=\overline{1, m}, j=\overline{1, l}$, $t=\overline{0, N}$ ). The second row includes the elements $u_{i t}^{2 j}$ - the size of effects following the realization of the corresponding control action.

Solving the optimization problem is a set of pairs of vectors $Z=\left\{\left(x_{0}, u_{0}\right),\left(x_{1}, u_{1}\right), \ldots,\left(x_{N-1}, u_{N-1}\right), x_{N}\right\}$ for each year. To solve the task one should find optimal set of controlling actions for each year, which will lead to the maximizing of function value $H(Z)$. This function is used to describe the integral indicator.

$$
H(Z)=\sum_{t=0}^{N-1} h_{t}\left(x_{t}, u_{t}\right)+h_{N}\left(x_{N}\right)
$$

where $\left(h_{t}\left(x_{t}, u_{t}\right)\right.$ - the value of integral indicator in the year $t$.

Therefore, finding the solution requires the following recurrent correlations:

$$
\begin{gathered}
f_{N}\left(x_{0}\right)=\max _{Z \in \Omega}[H(Z)]=\max _{u_{0} \in U\left(x_{0}\right)}\left[h_{0}\left(x_{0}, u_{0}\right)+f_{N-1}\left(Q\left(x_{0}, u_{0}\right)\right)\right], \\
f_{k}\left(x_{N-k}\right)=\max _{u \in U\left(x_{N-k}\right)}\left[h_{N-k}\left(x_{N-k}, u^{*}\right)+f_{k-1}\left(Q\left(x_{N-k}, u^{*}\right)\right)\right]
\end{gathered}
$$

where $k=\overline{1, N-1}$.

As a result of solving the optimization problem, we get a list of calculated indicators $x_{k}$, controlling actions $u_{k}$ and the value of indicators $h_{k}$ for each year for all $k=\overline{1, N-1}$. The values for $k=0$ and $k=N$ are set in advance. 


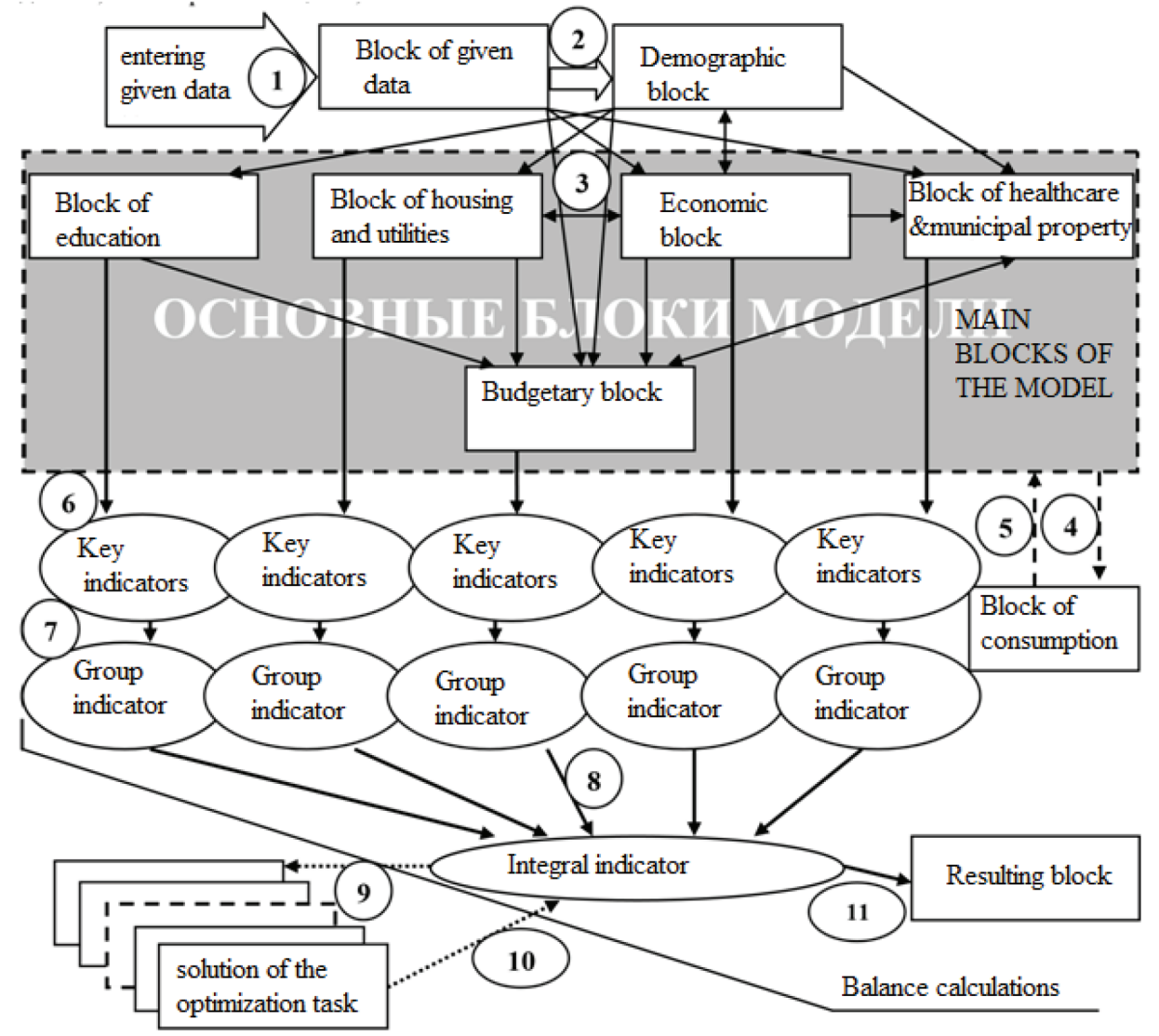

Fig. 3. The scheme of the model functioning

To understand how this model is working and the main directions of relationships between blocks you should look at Fig. 3 .

The demographic block is the basic one for this model. For this block we made prior calculations, whose results are used in the main model blocks (dotted lines, Fig. 3).

For population forecast in municipal unit and its structures we used S-formed logistic function, which is traditionally applied for describing the growth in human population.

To forecast the structure of human population and labour resources we used the modified formula of exponential average, which increases the meaning of trends of the last two years in the calculation of future values of indicators.

$$
\begin{gathered}
s_{t}=\left(\sum_{j=1}^{6} s_{t-j} / 6\right) \cdot 5 / 7+s_{t-1} \cdot 2 / 7 \\
-2268-
\end{gathered}
$$


where $S_{t}$ - the share of the corresponding indicator in the structure at the period $t$.

When we introduce the expert assessment of the population for a year or for some years, we reassess the indicators of the logistic function and recalculate the forecast for the whole programming period. This block impacts calculations in the consumer block, in which the consuming level and the amount of saving of population are estimated. The indicators are calculated based on obtained values after the balancing of model. The solution to the optimization task is found in case the expert assessments of socialeconomic indicators are used.

The demand for education, medical health care, social services and etc. is evaluated based on the resulting forecasts of demographic indicators and standards for the provision of social services with the forecasts made by experts or calculated in reliance on reference values of indicators. Thus, we are able to evaluate the level of satisfaction of demand and need for the construction of social facilities, the increasing number of staff, financial resources required for the construction of these facilities annually depending on the period of occurrence of unsatisfied need.

The calculations in the budget block take into account the calculations in other blocks. Each iterative calculation is supposed to be the final. The income of local budget $\left(\mathrm{OV}_{t}\right)$ during the period $t$ is formed by its own income $(\mathrm{OV})$ and also deductions from the federal budget for financing of expenditure obligations and in the form of governmental grants. The calculation of the accurate sum of grants for only one municipal unit is impossible, that is why we offer to use the dependence of the dynamics in the value of grants on the dynamics in municipal unit's own income as related to total expenditures of the local budget $\left(T B C_{t}\right)$. Besides, while in the previous year the budget of the municipal unit experienced surplus, the deductions from the federal budget did not increase. Having said that, we used the following formula for calculation in this model:

$$
T V_{t}=O V_{t}+\left(T V_{t-1}-O V_{t-1}\right) \cdot \sqrt[4]{\sqrt{\begin{array}{l}
1, T V_{t-1}-T B C_{t-1} \geq 0 \\
\frac{T B C_{t}-O V_{t}}{T B C_{t-1}-O V_{t-1}}
\end{array} \text { else. }}}
$$

The expenditures of local budget $T B C_{t}$, inter alia, include the expenditures of local budget on social programmes and also building social objects. The optimal order of realization of social projects, in turn, is determined during the solution of the optimization problem, taking into account the financial opportunities of budget, the 
latter depending on tax revenues and, as a consequence, the economic situation in the municipal unit.

Initial informational base of the calculations, according to the model, is data from Berdsk (small town near Novosibirsk). The resulting model was also successfully tested in another municipality of similar size - Kyzyl.

\section{Discussion of the results}

During the first stage of the study, carried out in 2016, we made the forecast calculation of the indicators of economic development for Novosibirsk for the period 2016-2035 on the basis of statistical data for 2010-2015 using the optimization model (dynamic modeling).

It should be noted that the statistics of 2010-2015 reflect stagnation in the Russian economy. Optimality criteria have negative dynamics, by 2035 their values will have been insignificant, but decreased. The "Economy" block predicts a sharp decline in productivity in all sectors in the first year to forecast. Moreover, according to calculations, in 2016 the volume of retail trade, the volume of paid services and the wage fund temporarily diminished.

After the first optimization of the forecast calculation we noticed that a number of key indicators improved in relation to the basic forecast: on average the increment of key indicators of the municipality was $11 \%$ at the end of the forecast period and for the education system this increment reached $53 \%$. In general, the results of the calculations are evaluated positively. Nonetheless, a more detailed examination of the results revealed the following specific features.

Throughout the forecast period, the savings of citizens ("Consumption" block) were reducing, in the first year of the forecast (2016) they trimmed down from 52 billion rubles to 2 billion rubles and by 2035 they will have demonstrated a deficit of 770 billion rubles. This is an extremely high value. The analysis showed that this result was the consequence of insufficient coverage of construction financing sources and the structure of the construction industry in Novosibirsk. The model initially assumes that the main source of construction financing is household disposable income and savings. In its main assumptions this approach was consistent with the situation in Berdsk and Kyzyl, where the construction industry is dominated by housing construction financed by households, while the structure of construction in Novosibirsk is characterized by a wide variety of facilities and funding is provided from numerous sources, including the regional budget, federal budget, funds of migrants and other sources. At the first stage 
of adaptation of the model to the Novosibirsk data, the peculiarities of the construction industry of the city were taken into account. For calculating the distribution of household funds we took into consideration the following indicators: the volume of direct housing construction, the share of housing purchased by migrants, the share of mortgage loans and financing from maternity capital, the share of retail turnover provided for by the guests of the city. As a result of the implemented adjustments, the optimized forecast of the household economy became more realistic. Despite the fall in the forecast of 2016 and 2017, the accumulated savings of households restore positive dynamics the next year.

According to the results of calculations and optimization, the budget of Novosibirsk remains balanced, at the level of 34-36 billion rubles per year (Table 1).

Table 1. The results of calculations of model parameters on the example of revenues of the municipal budget, million rubles

\begin{tabular}{|l|c|c|c|c|c|}
\hline \multicolumn{1}{|c|}{ Indicator } & 2015 & 2020 & 2025 & 2030 & 2035 \\
\hline Basic forecast & $34,408.4$ & $31,867.87$ & $31,674.6$ & $34,231.2$ & $34,294.2$ \\
\hline Optimized forecast & $34,408.4$ & $30,930.22$ & $31,971.1$ & $32,761.5$ & $33,044.9$ \\
\hline Improved forecast & $34,408.4$ & $33,486.16$ & $34,842.0$ & $35,491.4$ & $35,824.4$ \\
\hline
\end{tabular}

The initial forecast was obtained by extrapolating the existing dynamics of budget revenues in the period from 2010 to 2015, taking into account changes in the structure of revenue sources. This version of the forecast is characterized by plummeting in revenues in 2016-2018 (Fig. 4).

A $45 \%$ decline in revenues from a 2013 peak of almost 40 billion rubles to 22.6 billion rubles in 2016 would have extraordinary consequences for the financing of protected budget items and the municipal economy. The first application of the developed optimization algorithm allowed us to align the dynamics of the forecast of budget revenues with a minimum of 28.5 billion rubles (a decrease of $29 \%$ ). Improvements of the model carried out at the second stage, in particular, the clarification of the structure of income and expenditure of households, the structure of sources of the municipal budget in Novosibirsk, led to an even more smoothed dynamics of budget revenues. At the present stage of development of the model, according to the forecast, the budget's own revenues accounted for 32 billion rubles in the minimum value in 2017, i.e., the drop-in 


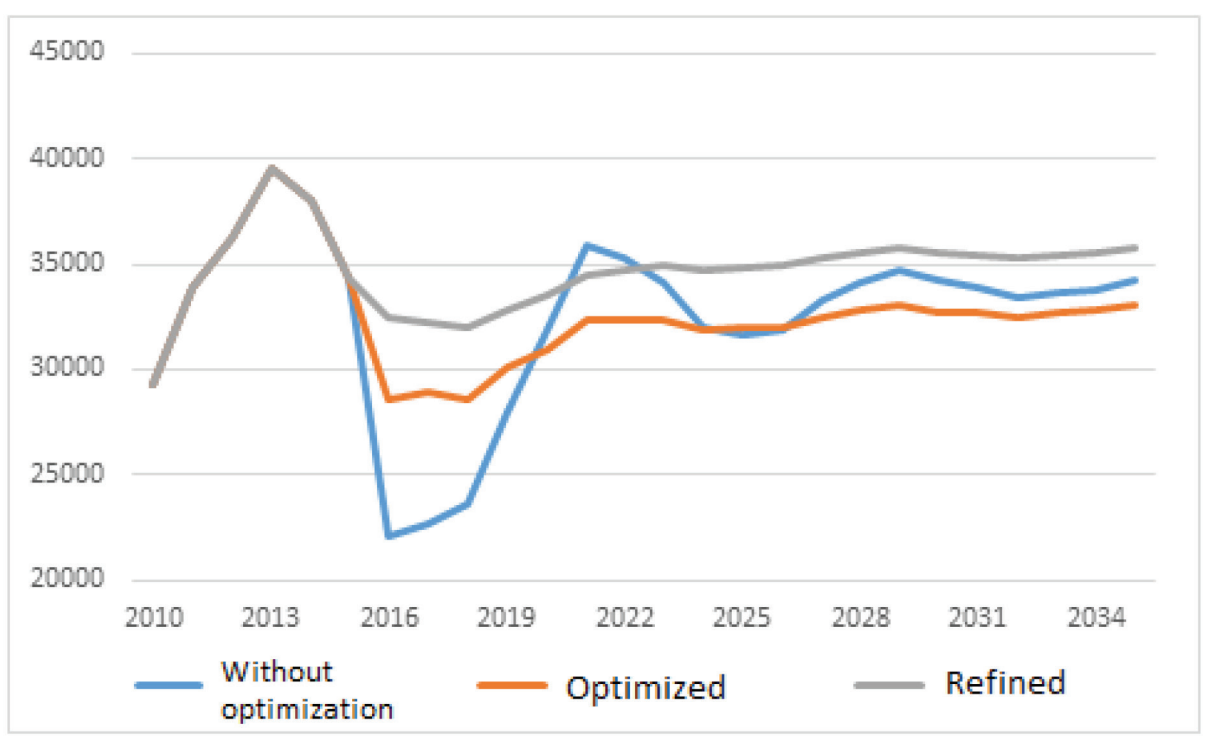

Fig. 4. Evolution of the forecast of budget revenues in Novosibirsk, million rubles

revenues compared to the peak year (2013) make up $20 \%$. By adjusting the revenue structure, a relative reduction in the expected budget deficit was achieved. Thus, in 2016 the deficit fell from 5 billion rubles per year to 1.4 billion rubles to attain surplus after 2021. The absence of long-term planning for inter-budgetary transfers complicates more elaborate forecasting for the Novosibirsk municipal budget. The result is undoubtedly and significantly affected by the absence of inflation factor in the model.

\section{Conclusion}

The initial use of the model allowed us to receive helpful results and adequate forecasts. Forecasting of the main development indicators for Novosibirsk has revealed the necessity of adapting the model regarding the features of this largest municipality. As a result of the model's improvement, we obtained a significant positive shift in the forecasts of the city's economic development. Our calculations have shown that in general the model can process real economic information and give a constructive result, but it needs adaptation considering the scale of the municipal unit and the peculiar features of social and economic progress.

The advantage of the proposed methodology is its high flexibility, speed of calculation and recalculation of possible scenarios for city's development, the possibility of using statistical data, expert estimates and forecasts for various indicators in the future. Development and application of such tools will accelerate finding new solutions, 
well-timed identifying problem areas and effective redistributing available resources in accordance with the selected criteria.

Balance-optimizing economic and mathematical model has been being developed and improved already for several years, during this time not only separate improvements concerning the model's parameters have been achieved, but also there has appeared an opportunity to check the correctness of previously made forecasts. Overall, the planactual analysis showed insignificant deviations as regards different parameters of the city budget. The data of the optimized forecast are mostly influenced by the tendencies of the last years presented by the actual data. However, in the long run, the internal proportions of indicators are being optimized regardless of considerable growth of the economy as a whole, which corresponds to the expectations expressed by leading economists, in particular, A.G. Aganbegyan, who studied the conditions of insufficient government participation in the modernization of the Russian economy.

The results of the research show that the very idea of using dynamic quantitative models to optimize and harmonize the development of municipal unit remains soughtafter and promising. It is essentially important that this tool can evolve in general, improve ahead of schedule in relation to the variability of the external environment. Thanks to the improvement of the model, it is possible to get a qualitative growth of indicators and provide an increase in the adequacy of its practical use in the management of socio-economic processes of the municipal unit.

\section{References}

Bayer, P., McMillan, R. \& Rueben, K. (2004). An Equilibrium Model of Sorting in an Urban Housing Market. NBER Working Paper, w10865. Cambridge, MA, 55 p.

Bergman, L., Jorgenson, D. \& Zalai, E. (Eds.) (1990). General Equilibrium Modeling and Economic Policy Analysis. Oxford, Basil Blackwell Inc., 466 p.

Biriukov, A.N., Glushchenko, O.I. (2006). Metodika dvukhurovnevogo raspredeleniiia munitsipal'nogo biudzheta na osnove neirosetevoi modeli [A Method of Two-level Distribution of a Municipal Budget Based on Neuronet Model]. In Vestnik Samarskogo universiteta [Bulletin of Samara State University], 8, 106-111.

Black, D., Henderson, V. (1997). Urban Growth. NBER Working Paper w6008. Cambridge, MA, 48 p.

Chernysheva, T. Iu., Zakharova, A.A., Mitsel', A.A. (2008). Ierarkhicheskaia model' otsenki sostoianiia sotsial'no-ekonomicheskogo razvitiia munitsipal'nogo obrazovaniia [Hierarchical Evaluation Model of Social and Economic Development of 
Municipal Unit]. In Izvestia Tomskogo politekhnicheskogo universiteta, [Bulletin of the Tomsk Polytechnic University], 313(6), 44-48.

Devarajan, S., Robinson, S. (1990). Policy Lessons from Trade-focused, TwoSector Models. In Journal of Policy Modeling, 12, 625-657.

Feler, L., Henderson, V. (2008). Exclusionary Policies in Urban Development: How under-servicing of migrant households affects the growth and composition of Brazilian cities. NBER Working Paper, w14136. Cambridge, MA, $50 \mathrm{p}$.

Gaiduk, E.A., Kovaleva, G.D. (2013). Munitsipal'noe obrazovanie v sisteme programmnogo upravleniiia [A Municipal Unit in the System of Programme Management], Novosibirsk, IEOPP SO RAN, $230 \mathrm{p}$.

Granberg, A.G. (1985). Dinamicheskie modeli narodnogo khoziiaistva [Dynamic Models of National Economy]. Moscow, "Ekonomika", 240 p.

Henderson, J., Wang, H. (2005). Urbanization and City Growth. In Journal of Economic Geography, 5, 23-42.

Kingsland, S.E. (1995). Modeling Nature: Episodes in the History of Population Ecology. Chicago, University of Chicago Press, 267p.

Krakashova, O.A. (2008). Ekonomiko-matematicheskaiia model' finansirovaniia razvitiia kommunal'noi infrastruktury munitsipal'nogo obrazovaniia [EconomicMathematical Model of Financing Communal Infrastructure of Municipal Unit]. In Sibirskaia finansovaiia shkola [Siberian Financial School], 6, 20-25.

Leksin, V.N. (2012). Rezul'tativnost' i effektivnost' deistvii regional'noì i munitsipal'noi vlasti: naznachenie i vozmozhnost' korrektnoi otsenki [Effectiveness and Efficiency of the Activities of Regional and Municipal Governments: Purpose and Possibility of Correct Assessment]. In Region: ekonomika i sotsiologiia [Region: Economics and Sociology], 1, 3-39.

Lofgren, H., Harris, R.L. \& Robinson, S.A. (2002). Standard Computable General Equilibrium (CGE) Model in GAMS. Washington D.C., International Food Policy Research Institute, $69 \mathrm{p}$.

Lucas, R.E. (1988). On the Mechanics of Economic Development. In Journal of Monetary Economics, 22 (7), 3-42.

Marshalova, A.S., Novoselov, A.S. (2011). Munitsipal'nye obrazovaniia i innovatsionnoe razvitie ekonomiki [Munipal Units and Innovation Development]. In Region: ekonomika i sotsiologiia [Region: Economics and Sociology], 1, 225-234.

Mitsel', A.A., Zakharova, A.A. (2005). Primenenie nechetkikh lingvisticheskikh modelei pri razrabotke strategii razvitiia munitsipal'nogo obrazovaniia [Application of 
Non Distinctive Linguistic Models during Elaboration of the Strategies for Municipal Unit Development]. In Izvestiia Tomskogo politekhnicheskogo universiteta [Bulletin of the Tomsk Polytechnic University], 308(4), 177-182.

Novoselov, A.S., Gaiduk, E.A., Kovalev, A.E. (2016). Modelirovanie strategicheskogo razvitiia munitsipal'nogo obrazovaniia [Modelling of Municipal Unit Strategic Development]. In Vestnik Kuzbasskogo gosudarstvennogo tekhnicheskogo universiteta [Vestnik of Kuzbass State Technical University], 4, 123-132.

Novoselov, A.S., Marshalova, A.S., Burmatova O.P. (2018). Strategicheskoe upravlenie regional'nym $i$ munitsipal'nym razvitiem [Strategic Management of Regional and Municipal Development]. Novosibirsk, IEOPP SO RAN, 496 p.

Rossi-Hansberg, E., Wright, M. (2006). Urban Structure and Growth. Federal Reserve Bank of Minneapolis Research Department Staff Report, Minneapolis, 53 p.

Seliverstov, V.E. (2016). Sibirskaia shkola strategicheskogo planirovaniia [Siberian School of Strategic Planning]. Novosibirsk, IEOPP SO RAN, 199 p.

Tscharaktschiew, S., Hirte, G. (2009). An Urban General Equilibrium Model with Multiple Household Structures and Travel Mode Choice. Dresden Discussion Papers in Economics, 06/09, Dresden, 40 p.

Verhoef, E., Nijkamp, P. (2003). Externalities in the Urban Economy. Tinbergen Institute Discussion Papers, 078/3, Amsterdam, Tinbergen Institute, 28 p.

\title{
Опыт разработки
}

\section{балансово-оптимизационной модели развития крупного муниципального образования}

\author{
А.С. Новоселов, А.Е. Ковалев, \\ Е.А. Гайдук, Г.М. Мкртчян \\ Институт экономики и организацчи \\ промышленного производства СО РАН \\ Россия, 630090, Новосибирск, \\ пр. Академика Лаврентьева, 17
}

Целью исследования является построение балансово-оптимизационной динамической модели, позволяющей обеспечить прогнозирование устойчивого поступательного развития крупного мунищипального образования. На основе метода динамического программирования Ричарда Беллмана авторами разработана экономико-математическая модель, оптимизирующая ключевые показатели развития муниципального образования. В модели используются и прогнозируются показатели, включенные в список 
базовых факторов оценки эффективности деятельности администраџии муниципального образования. Сделан анализ результатов применения модели для прогнозирования развития крупного мунищипального образования на примере Новосибирска. Расчеть показали, что модель способна работать с реальной экономической информаичей и может использоваться для прогнозирования и принятия управленческих решений на муниципальном уровне.

Ключевые слова: моделирование, прогнозирование, стратегическое планирование, управление, мунищипальное образование.

Исследование выполнено по плану НИР ИЭОПП СО РАН по проекту ХІ.173.1.2. «Стратегическое управление региональным и муниципальным развитием: концепция и приниุипь реализации» № АAAA-A17-117022250118-6.

Научная специальность: 08.00.00 - экономические науки. 